\title{
Typical Features of the Moscow Russia as Early-modern State in the Context of the Comparative and Legal Analysis
}

\author{
Gennady A. Borisov ${ }^{1}$, Vladimir G. Krikun ${ }^{1}$, Victoria V. Kutko ${ }^{1}$, Vitaly V. Penskoy ${ }^{1} \&$ Svetlana V. Sherstobitova $^{1}$ \\ ${ }^{1}$ Belgorod State University, Belgorod, Russia \\ Correspondence: Gennady A. Borisov, Belgorod State University, 85 Pobedy St., Belgorod, 308015 Russia. \\ E-mail: russia@prescopus.com
}

Received: April 19, 2017

doi:10.5539/jpl.v10n3p121
Accepted: April 27, $2017 \quad$ Online Published: June 1, 2017

URL: https://doi.org/10.5539/jpl.v10n3p121

\begin{abstract}
In this article features of political regime development in the Russian state of the Moscow era (the end of the XV-XVII centuries) are considered in the general context of the European early-modern states of the XVI-XVII centuries formation and evolution. Use of new methodological approaches and deeper and at the same time original approach to the analysis of both narrative, and assembly materials allow to conclude that, despite unusual, at first sight, features of development of the Russian state during the considered period (those natural and geographical conditions caused first of all by character it developed in), Russia can be put in one row with such early-modern states as France, Spain or the Ottoman Empire. For all of them who are not possessing the developed officialdom and so developed fiscal institutes and power tools (represented by regular army, police and so forth), the aspiration to find a certain balance of interests between raison d'État (understanding as it first of all interest dynastic) and bien public (that it is first of all interest of the most active and influential part of society, "the political nation" in the political plan) as it guaranteed the power necessary legitimacy, obedience and support from society as indispensable conditions of more or less effective functioning of power institutes is inherent.
\end{abstract}

Keywords: early Modern times, early-modern state, political institutes, political regime, Western Europe, the Ottoman Empire, Russian state

\section{Introduction}

The imperial diplomat baron S. Gerberstein, characterizing the power of the Moscow grand duke Vasily III, noted that "in the sway which he holds over his people, he surpasses all the monarchs of the whole world" and he "oppresses nearly all of them with close confinement" $[1,30]$. This statement of the author which is noncritically apprehended by the latest authors and historians generated the perception of early-modern Russia dominating both in historical and legal literature, and in public opinion as country Asian in essence, and its political regime as despotic that opposed it to the European states of that era which political regimes differed in bigger freedom.

This point of view so strongly was fixed in consciousness of scientific organization that up to the last time neither in Russia, nor in Europe serious attempts to reconsider it with a support not only and not just on the historical narrative to a greater or lesser extent having pronounced subjective character and dependent on political and other addictions of his creators how many on assembly materials and studying accepted in Russia political, administrative, legal and jurisprudence, especially in a comparative-historical context were not made. Perhaps, the first and serious attempt such was made by the American historian V. Kivelson in 1996 in its research "Autocracy in the Provinces. The Muscovite Gentry and Political Culture in the Seventeenth Century" [2].

The essence of the new interpretation of the Moscow monarchy and a political regime offered by it in the Moscow Russia was that just as and in other European states of early Modern times, the power needed Moskovia and looked for support in society, in its various layers. The last used this requirement to protect within the operating political system (which they besides and created the actions) the rights and interests.

V. Kivelson laid if it is so possible to be expressed, the road to other researchers - as foreign (we will note in this regard works of the French historian A. Berelovich and the American researcher N. Kollmann [2: 3: 4]), and Russian $[5 ; 6 ; 7]$. Their point of view on essence of a political regime and the nature of relationship of the power 
and society in early-modern Russia (first of all "the political nation") to a greater or lesser extent corresponded to the conclusions received V. Kivelson. Naturally, as supporters of an old look did not stand aside, protecting the settled point of view [see., for example: 9]. The discussion around the lifted problem allowed to specify a number of the aspects connected from processes of the state construction in Russia of early Modern times in comparison with similar processes in the early-modern states of Europe [See, for example: 10; 11].

\section{Technique}

Developing the problems connected with formation of the Russian centralized state we recognized that, first, weakness of the central power and its institutes assumed its cooperation with groups of influence on places. As a result, local provincial elite received real levers of impact on the power and used this opportunity for protection of the rights and privileges. Secondly, both the Russian society of that era in general, and the court environment in which the Moscow grand dukes were brought up was conservative in essence and at all did not welcome innovations, especially innovations political. Their "center-forming" policy was aimed at fight against the persons breaking the settled order, but not with order per se. Therefore special character of the relations connecting the center and the province was established. For the characteristic of such order of management the British historian of J. Elliott suggested to use the term "Composite Monarchu" ("Composite State") [12. Cf.: 13; 14]. Russia of early Modern times, in our opinion, represented typical "Composite State", and through a prism of this approach we also will consider its political development at this time.

\section{Discussion and Results}

Characterizing a political regime of early-modern Russia through a concept of "the centralized state", we will provide its classical characteristic: "Formation of the centralized state included two interconnected processes: formation of the uniform state territory due to association of Russian lands and establishment of the real power of the uniform monarch over all this territory (it is allocated by us - auth.) ..." [15. 8]. Process of "centralization" formally in itself was excessive as even in the worst times after the Tatar-Mongolian invasion political and legal the unity of the Russian land (at least, its northeast part) remained. The Russian land both then, and before, was "family" possession of princes from a dynasty of Ryurik dynasty from whom the grand duke Vladimir, heading interprincely hierarchy was considered as the senior. However owing to the objective reasons by the end of the 13th century the power of grand Vladimir dukes significantly weakened, princes excessively bred, the relations between them, first of all the relations of inheritance of tables and "отчин" got confused that promoted an aggravation of interprincely contradictions and fight between them.

Within the 14th century in this fight the Moscow princes won. They managed to hold in the hands given out by the Supreme sovereigns of the Russian land, the Horde khans, the diploma label on the grand duchy Vladimir, giving to its owners the Supreme power in northeast Russia.

Vasily II, having overcome the enemies, thoroughly "smoothed out" political space of Northeast Russia, having removed practically all other specific princes whose loyalty he could doubt, not to mention those who battled on the party of his opponents. His son Ivan III practically completed auth.iness begun by the father, having collected the most part of the Russian land under the power. In this regard it is possible to compare its actions to policy of the French king Louis XI or to events of the English war of Roses.

However, having achieved political unity of the Russian land, Ivan III as it was already noted above, faced a serious problem. The administrative facilities which were under his hand and resources which it had formations of the territory of the Russian state were obviously inadequate to the new tasks and new problems which resulted accelerated, during lifetime one generation. The deadlock was broken on the way of formation of that "Composite State" about which J. Elliott wrote (in his Russian option which we would call "the scrappy state"). He noted that in the Western European early-modern states the royalty, attaching new territories, faced a problem which at first sight seemed insoluble - how to adjust more or less effective management of acquired territories. And, supporting constant military control over them (here it, centralization military!), the crown built on (it is allocated by us - auth.) over the remaining habitual power structures (and closely related customs and traditions in administrative and legal spheres) own [12. 55. Cf.: 14. 191-216]. At the same time, keeping old "liberties" of local elite in firmness, the royalty widely used institute of patronage to achieve and keep loyalty of local administrative and political elite. In Russia, N. Kollmann, "noted as in early modern Europe, personal networks among clan-based factions structured politics. The language and practice of "feeding," "gifts" and tsarist "favor", and the politics of patronage and clientism, coexisted with legal definitions of law and procedure" [4. 99].

In the analysis of the assembly materials which came out offices of Ivan III and his successors it is easy to notice that this practice was widely used by them for establishing management of sharply increased state territory. For example, the same Ivan III in the message to Novgorodians wrote that he in the claims to Novgorodians, does 
not go beyond that legal framework that were outlined in the former contracts signed between his ancestors, grand Vladimir dukes, and Novgorod. At the same time Ivan reminded Novgorodians that, favoring Novgorodians "old times", he equally within these "old times" has the right to punish Novgorodians if they try to break the settled tradition and custom [16.285].

The form of the diplomas "feeding" which were given by clerks of the grand duke to the deputies sent to the province can serve as not less striking example confirming this thesis. It was accurately and unambiguously specified in these diplomas that the deputy, carrying out justice and daily administration, had to be guided by "old times", "old custom". And, as the deputy came to the province for the short term (usually for a year, is rare more), it inevitably had to interact with local elite, use the local administrative facilities which developed before and regularly functioning long before its emergence, territorial self-government (sotsky, dvorsky, desyatsky and so forth).

At the same time the local "territorial" government felt rather surely - to such an extent that it sometimes worked contrary to appointed immunity monarchic diplomas, assessing their owners with former taxes and duties of which they tried to get rid through these grand-ducal acts [See, for example: 17. 116-117]. The reason of such "arbitrariness" becomes clear if to assume that obtaining such immunity diplomas meant violation of "old times" which defender had to be a grand duke, and local officials restored old habitual regime. At the same time the grand-ducal power, fighting against such arbitrariness of local authorities, nevertheless, took under the protection local communities in case the deputies sent from Moscow abused the powers.

As result, an attendance way there was a situation which the Russian researcher V. V. Bovykin characterized as interaction of two subjects - unequal, of course (their relationship it is possible to designate as the relations of the senior and younger partners), but nevertheless subjects of legal relations, the center and the province [7. 93]. However, differently also could not be. As the Russian historian M. M. Kr studying features of functioning of the central administrative facilities in the 2nd quarter of the 16th century noted the last owing to the weakness and small number did not cope with the growing loading and transferred a part of the functions on places, to territorial self-government [8. 374-375].

\section{Conclusions}

Summing up the general result of all aforesaid, it is possible to declare with confidence that the statement of S. Gerberstein with which we began this article is, at least, strong exaggeration and in a sense a sight aberration. Owing to any reasons the imperial diplomat did not begin to penetrate in particular relationship of the center and local government. As a result the biting phrase laid the foundation for tradition of perception of Russia as the despotic state distinguishing from modern to it the Western European states. Meanwhile, as shows careful and impartial studying of assembly materials, such representation is very far from reality. Also it is only possible to agree with opinion N. Kollmann who, comparing the way passed by the Russian state in the XVI-XVIII centuries to on what these centuries the European states moved, noted: "From 1500 to 1800, Russia developed a powerful early modern empire. It did so in ways common to its European and Ottoman peers, ways that balanced the rulers' claims to monopolize violence and resource extraction with opposing claims emanating variously from privileged nobilities and municipalities, tribal elites, religious establishments or popular concepts of justice. In all these states, legitimacy was grounded not only in the measured deployment of state-sanctioned violence, but also in the state's fulfillment, to a greater or lesser degree, of expectations that the ruler would respond to his people, respect tradition and provide security. Such expectations were expressed in religious-political discourses from France's increasingly secular royal absolutism to the Ottoman sultan's Sunni Islam, and delivered with mechanisms such as distribution of benefits to elites, preservation of local autonomies and flexibility in governance. Early modern states thrived on a bricolage of legal and institutional rationality and pluralistic informality". At the same time, she, "specified into the patterns of state building, local governance and adjudication seen in some of its early modern peers in Europe and the Ottoman Empire. On the ground adjudication in early modern states had much in common. Centralizing states in Europe had to deal with established social groups and solidarities - nobilities and gentries, guilds, strong regional customs - and consequently local justice was often moderated to suit local needs. The same in Russia" [4. 416, 425]. The political regime based on interaction of the center and the province, the grand-ducal power and local government, in mutually beneficial cooperation of two, senior and younger, legal entities, Moscow could not be despotic.

\section{References}

Akty sotsialno-ekonomicheskoj istorii severo-vostochnoj Rusi kontsa XIV nachala XVI vekov. (1952). [Acts of social and economic history of north-eastern Russia in the late XIV early XVI centuries] Moscow: Publishing House of the USSR Academy of Sciences, Vol. I: 810. [in Russian]. 
Arakcheev, V. A. (2014). Vlast i zemlya. Pravitelstvennaya politika v otnoshenii soslovij v Rossii vtoroj poloviny XVI nachala XVII veka [Power and land. The government policy concerning estates in Russia in the late XVI early XVII centuries]. Moscow: Depository of ancient manuscripts, 512. [in Russian].

Berelowitch, A. (2001). La hierarchie des egaux. La noblesse russe d'Ancien Regime (XVI-XVII siecles). Paris: Editions Seuil: 480.

Black, J. (2004). Kings, Nobles and Commoners. States and Societies in Early Modern Europe. A Revisionist History. London and New York, Routledge: 203.

Bovykin, V. V. (2012). Mestnoe samoupravlenie v russkom gosudarstve XVI veke [Self-governance in the Russian state in the XVI century] .Saint-Petersburg: Dmitrij Bulanin, 421 [in Russian].

Elliott, J. H. (1992). A Europe of Composite Monarchies. Past \& Present. The Cultural and Political Construction of Europe, 137, 48-71. https://doi.org/10.1093/past/137.1.48

Halperin, C. J. (2002). Muscovy as a Hypertrophic State: A Critique. Kritika: Explorations in Russian and Eurasian History, 3(3) (New Series), 501-507. https://doi.org/10.1353/kri.2002.0036

Herberstein, S. F. (1851). Notes upon Russia: Being a translation of the earliest account of that country, entitled Rerum Moscoviticarum Commentarii (Vol. 1). Hakluyt Society: London: 294.

Kivelson, V. A. (1996). Autocracy in the Provinces. The Muscovite Gentry and Political Culture in the Seventeenth Century. Stanford. Stanford University Press: 396.

Koenigsberger, H. G. (1978). Monarchies and Parliaments in Early Modern Europe Dominium Regale or Dominium Politicum et Regale. Theory and Society, 5(2), 191-217. https://doi.org/10.1007/BF01702161

Kollmann, N. S. (1999). By Honor Bound: State and Society in Early Modern Russia. Ithaka \& London, Cornell University Press. Retrieved from http://www.jstor.org/publisher/cornellpress

Kollmann, N. S. (2012). Crime and Punishment in Early Modern Russia. Cambridge, Cambridge University Press: 504. https://doi.org/10.1017/CBO9781139177535

Krom, M. M. (2010). "Vdovstvuyushhee tsarstvo": politicheskij krizis v Rossii 30 - 40 godov XVI veka ["Widowed tsardom": political crisis in Russia in the 30-40s of the XVI century]. Moscow: Novoe literaturnoe obozrenie, 888. [in Russian].

Moskovskij letopisnyj svod kontsa xv veka. polnoe sobranie russkix letopisej. (2004). [Moscow Chronicle of the late XV century. Complete collection of Russian chronicles]. Moscow: Yazyki slavyanskoj kultury, Vol XXV: 488. [in Russian].

Poe, M. (2002). The Truth about Muscovy. Kritika: Explorations in Russian and Eurasian History, 3(3) (New Series), 473-486. https://doi.org/10.1353/kri.2002.0044

Rossijskoe zakonodatelstvo X-XX vekov. (1984). Zakonodatelstvo perioda obrazovaniya i ukrepleniya russkogo centralizovannogo gosudarstva [Russian legislation in the X-XX centuries. The legislation of the period of the formation and consolidation of the Russian centralized state]. Moscow: Yuridicheskaya literatura, Vol. 2: 520. [in Russian].

Rustemeyer, A. (2010). Systems and Senses: New Research on Muscovy and the Historiography on Early Modern Europe. Kritika: Explorations in Russian and Eurasian History, 11(3) (New Series), 563-579. https://doi.org/10.1353/kri.0.0180

\section{Copyrights}

Copyright for this article is retained by the author(s), with first publication rights granted to the journal.

This is an open-access article distributed under the terms and conditions of the Creative Commons Attribution license (http://creativecommons.org/licenses/by/4.0/). 